Borneo Journal of Sciences and Technology, Volume (1), Issue (1), Pages: 15-20

DOI: https://doi.org/10.35370/bjost.2019.1.1-04

e-ISSN: 2672-7439

(C) 2018, UCTS Publisher.

Submitted: 9 October $2018 \quad$ Accepted: 12 October $2018 \quad$ Published: 31 January 2019

\title{
Application of Online Halal Label Among Consumer Intention Toward the Halal Label System in Malaysia
}

\author{
Zul Ariff Abdul Latiff, Noor Zariana Kasim, Nor Amilia Din, Nornadillanadia Abdul Rapar, Norhidayah \\ Yakob, Farah Nur Amalina Mohd Ramli, and Nursalwani Muhamad
}

Faculty of Agro Based Industry, Universiti Malaysia Kelantan, 17600 Jeli, Kelantan

\begin{abstract}
Halal products must be healthy and safe for consumers. With nowadays technologies, the media sometime manipulates the old stories and invalid news to become viral through media social that fast delivered to consumers that make consumers more believes to the story that is not true. With the existence of the application of online Halal label system in Malaysia, the consumers can check the authenticity of the news. The intention level can be increased regarding the application of online Halal label system among consumers intention toward Halal label system in Malaysia. Application of online Halal label system in Malaysia influenced by many factors among consumer intention toward halal label. The present study has assessed to investigate the application of online Halal label among consumers intention toward the Halal label system in Malaysia based on the Theory of Planned Behaviour (TPB). Data were gathered from a self-reported questionnaire completed by 108 consumers on the questionnaire paper located at Malaysia International Halal Show (MIHAS) on Kuala Lumpur, Malaysia. Four underlying factors were assumed and extracted, including attitudes toward the application of online Halal label system in Malaysia, subjective norms, perceived behaviour control and intention among consumers. There is significantly relationship found between sociodemographic and intention of consumers toward Halal label in Malaysia. Relationship between different demographic information with intention of consumers was observed. The study contributes positive feedback of the application of online Halal label system among consumer intention toward the Halal label system in Malaysia and the TPB.
\end{abstract}

Keywords: Halal, online, label, intention, attitudes.

\section{INTRODUCTION}

The worldwide food market has experienced key transformations because of shifts in taste, preferences, lifestyle and higher education levels and salary. Customers are shifting for better excellence, healthier, and handier foodstuff. Amid Muslim people worldwide, the Halal food demand keeps increasing. Customers are improving from better foodstuff choice on market in this time of globalization. By introducing innovative and distinguished products to the food retail, foodstuff producers making a chance in order to increase the company of theirs in areas to improve their profit [1]. The foodstuff commerce needs to answer request and wants that customers much like other industries. Nowadays, people of all religions around the world always exploring toward uncontaminated, safe, hygienic, and clean foodstuff. Majority people of religion other than Islam in Malaysia are inclining to favour foodstuff products that has Halal label for the sake of health [2]. The epidemic of lethal illnesses like mad cow and bird flu virus sickness which happened recently has caused this preference to particularly surged. The safety part of foodstuff stock is turning a main worry for shoppers globally because of that motive. Customers that are Muslim, approaching spiritual necessity are one of the fundamental goals [3]. Muslims too wish those foodstuffs they eat are clear of parasites \& toxic elements and also healthy.

Malaysia is a rapid thriving economy that have significant amount of the people turning into more open-minded toward harmless and healthful foodstuff. Therefore, it is to no surprise that Malaysia people are displaying toward more awareness when buying and eating healthier and wholesome foods [3]. Apparently, there is a significant major degree of purchasers' awareness \& curiosity toward halal essence of foodstuff because of the diverse variety of Malaysia people and its civilization, where Islam is major spiritual society. This is not just because of spiritual motives but getting certainty result making certain consuming halal foodstuff promises healthier lifestyle. Mentally, customers' approach about foodstuff labelling might partake an enormous consequence toward eating the 


\section{Application of Online Halal Label Among Consumer Intention Toward the Halal Label System in Malaysia}

foodstuff. Most of Muslims at Malaysia have a solid certainty of the values of halal and haram that may be connected to passionate \& behavioural result toward buying and eating of any foodstuff [4].

Foodstuff and beverage like alcohol and pork are marked prohibited and also unwholesome and destructive establish from certainty value of haram. These general spiritual principles and values incline can make a worldwide consequence because Muslims worldwide grasp to the belief. This may be associated toward statement state that purchaser industry inside Islam country worldwide, becoming thriving rising internationally, that have something to do with spiritual principles and obligation, attached along with exceptional capacities of pure and healthful that can be found inside halal foodstuff.

The market for certified Halal food and goods is increasing sturdily internationally. As a measure for food security and quality guarantee, Halal products accepted universal acknowledgement. Where Muslims are the majority people in Malaysia, Halal products are the complete vital for eating. In designated that food products that are certified with Halal accreditation are unquestionably accepted by Muslim purchasers as well as non-Muslims customers. This agreement is owed to the entire notion of halal which covers the Shariah obligation from the feature of Islam as well as the hygiene, sanitation and safety aspects [5].

According to [6], the Theory of Reasoned Action (TRA) had been formulated in 1980 by Ajzen and Fishbein. It was resulted from the Expectancy Value Models after the estimation attitude and behaviour discrepancy. It was not $100 \%$ of behaviour appear to be voluntary and been controlled as bring the result of perceived behaviour control. It was being called as theory of planned behaviour. The theory deliberate behaviour which can be deliberative and planned. TRA also help in identification of the primary determinant behaviour and source of determinant behaviour. It was based on the organizing of the relation between the variables. TRA are been marked by the sequences of reformulation. In result, there were the build of on a development fashion. It also indicates in the explanation of behaviour changing. TRA helps in identification of accomplishment of and opportunities for research in the reasoned action traditional [7]. Customer's intention in purchasing the product are based on their behaviour and social influence. Subjective norm stated that the measurement of the social influencing on a person's behaviour. This social influence may be those who are very close to that person like the opinions of family as well as friends. TRA can be the model in prediction of customer intention in application of online Halal label system in Malaysia.
TPB or standard to be called Theory of planned behaviour is one of the best suited to explain a variety of behaviours within entrepreneurship. TPB is suitable to explain any behaviour which requires planning, such as entrepreneurship [6].

However, human usually behave in a reasonable way, they consider their behaviour based on available information, and implicitly or explicitly consider the consequences of their actions. Behaviour is based on wills that involves considerations for performing or not conducting behaviour; where in the process, the various considerations will form the intention to conduct behaviour [6].

In theory of reasoned action, it is stated that the intention to conduct behaviour has two main predictors, namely attitude toward the behaviour and subjective norm. The development of this theory, planned behaviour theory, finds other predictors that also influence the intention to perform behaviour by incorporating the concept of perceived behavioural control. So that, there are three main predictors that influence the intention of the individual to conduct a behaviour which is attitude toward the behaviour, subjective norms of a subjective behaviour, and perception of behavioural control [6].

Theory of planned behavioural is based on an approach to beliefs that can encourage individuals to perform certain behaviours. Approach to beliefs is done by associating various characteristics, qualities, and attributes based on information that has been owned, then automatically will form the intention to behave. The approach in planned behaviour theory is specific to the specific behaviour of the individual and can be used for all behaviours in general.

The influence of attitude toward the behaviour, subjective norm, and perceived behavioural control of the intention to perform a behaviour determined by the intention behave that will be described. The magnitude of attitude toward the behaviour, subjective norm, and perceived behavioural control effects may vary from one individual to another or from one population to another [6].

Specifically, in the planned behaviour theory, attitude toward the behaviour is defined as the degree of positive or negative judgment of an individual toward behaviour. Attitude toward the behaviour is determined by a combination of individual beliefs about the positive and / or negative consequences of doing behavioural beliefs with the individual's subjective value for each of the consequences of the behaviour.

In general, the more individuals have an assessment that behaviour will produce positive consequences then the individual will tend to be favourable towards the behaviour; on the contrary, the more individuals have an assessment that behaviour 
Application of Online Halal Label Among Consumer Intention Toward the Halal Label System in Malaysia

will result in negative consequences then the individual will tend to be unfavourable towards the behaviour [6].

Furthermore, in the planned behaviour theory, subjective norms about a particular behaviour (subjective norm) are defined as individual perceptions of social pressure to perform or not to conduct behaviour. The subjective norm is determined by the combination of individual beliefs about the agreement and or disagreement of a person or group that is important to the individual to behaviour (normative beliefs), with the motivation of the individual to adhere to the reference which being motivated to be comply.

Motivation is a way to comply as one of the things that influence the value of subjective norms about behaviour is influenced by social forces. The social forces in question consist of rewards or punishments given by the source of reference to the individual, the individual's liking to the source of reference, how much the individual perceives the referral source as an expert, and the demand from the referral source.

However, in planned behaviour theory, perception of behaviour control or more to call as perceived behavioural control is defined as individual perception about the ease or difficulty to perform behaviour. Perceived behavioural control is determined by a combination of individual beliefs about the supporting factors and / or inhibitors to perform a behaviour (control beliefs), with the individual's perceived power control of each of the perceived power factors.

Whereas, in general, the more individuals perceive many supporting factors and the few inhibiting factors to be able to perform a behaviour, the individual will tend to perceive themselves easily to perform the behaviour; on the contrary, fewer individuals perceive fewer supporting factors and many inhibiting factors to perform a behaviour, then individuals will tend to perceive themselves difficult to perform such behaviour [6].

In TPB methods there are several external factors that affecting which is attitude toward the behaviour, subjective norm, and perceived behavioural control as stated above. Based on the planned behaviour theory, there are three variables that determine the intention, and which are attitude toward the behaviour, subjective norm, and perceived behavioural control. These three variables influenced by various external factors owned by individuals. In other words, individuals who grow and develop in different social environments will get different information about things that can be the determinant of attitude toward the behaviour, subjective norms, and perceived behavioural control that individuals have.

\section{MATERIALS AND METHODS}

\section{Framework Design}

Theory or concept that had been used in this study is the Theory of Planned Behaviour (TPB). Generally, TPB theory was intended to predict and explain the relationship between individual's intention to express in behaviour, attitude and subjective norms at a certain time and place. Thus, TPB is likely to express the relationship between the subjective norm, perceived behaviour control and attitude of Malaysian consumer towards intention of application of online Halal label system in Malaysia. The key component to this model is including attitudes toward the application of online Halal label, subjective norms, perceived behaviour control and intention among consumers. Attitude factors in TPB theory is more toward consumer belief, opinion and perception toward online Halal label system in Malaysia. Furthermore, subjective norms may influence consumer to used online Halal label system from many sectors included government, mass media, seminar and many more in many ways. In addition, perceived behaviour control is stage where consumers likely to perform particular behaviour toward application online Halal label system and they directly can control it. Lastly, intention is phase where consumers realizes the important of application of online Halal label and wants to use it as influenced over their lifetime [8].

\section{Pilot survey}

Pilot questionnaire surveys were conducted at UMK campus Jeli among students, staff and lecturers who are consumers and have Malaysia nationally. The total respondent was 31 consumers. The questionnaire was similar to the real survey. The aim to conduct pilot questionnaire surveys is to know either the question is valid or not and respondent understand or not. This can be observed by the data collected when the value of reliability analysis was higher than 0.6 , then it is reliable to continue and can be conducted as a survey [9]. There are four factors which are attitude, subjective norms, perceived behaviour control and intention analysed for reliability test. Cronbach's Alpha of Reliability statistics for four factors namely attitude, subjective norms, perceived behaviour control and intention were $0.953,0.938,0.938$ and 0.976 respectively.

\section{Sample}

A questionnaire survey was carried out in April 7, 2018 through paper questionnaire at MIHAS, Kuala Lumpur, Malaysia. We received 108 completed questionnaires. 
Application of Online Halal Label Among Consumer Intention Toward the Halal Label System in Malaysia

\section{Statistical and Analysis}

There are three analysis method had been used in this study which are descriptive analysis, reliability analysis and Pearson Correlation analysis. Descriptive analysis was used to describe and analyse basic features of the data which is demographic information which provide summary about the sample and factor together in form of graphic or more [10]. Then, reliability analysis to examine either the question is valid and can be extent to study or not. The higher the reliability of the factors used, the lower the errors when distributed and conducted the survey [11]. Pearson correlation analysis is to determine and measures the statistical relationship between two quantitative, continuous variables which will provide information about magnitude of association, correlation and the direction of the relationship in term OD covariance method [12]. It also shows the strength of the association between two variables such as age and attitude of consumer toward application on online Halal label in Malaysia.

\section{RESULTS AND DISCUSSION}

\section{Socio Demographic}

Table 1 shows the social demographic profile of respondents by the variables of gender (male and female), race (Malay, Chinese, Indian and others), age (21-30.31-40,41-50,51-60 and 60 and above), education level (no education, primary school, secondary school, diploma/STPM, degree and postgraduate/PhD), Income of the family (< RM 500, RM 501-RM 1000, RM 1001RM 2000, RM 2001-RM 3000, >RM 3000) and employment status (self-employment, government sector, private sector, retired, unemployment).

Gender frequency is mostly female: 68 females $(63 \%)$ while the number of males is $40(37 \%)$. Most race is Malay $(88.9 \%)$, followed by 7 Chinese $(6.4 \%), 2$ Indian (1.9\%) and 3 others (2.8\%). Most age is between 21-30 years represented by 82 people $(75.9 \%)$, followed by 31-40 years by 17 people (15.8\%), 41-50 years by 5 people $(4.6 \%), 51-60$ years by 3 people $(2.8 \%)$ and year 60 -above by 1 people $(0.9 \%)$. Mean and standard deviation for age are 1.37 and 0.781 respectively.

Most education level is diploma/STPM represented by 52 people ( $48.2 \%)$, followed by degree by 32 people (29.6\%), secondary school by 15 people $(13.9 \%)$ and postgraduate $/ \mathrm{PhD}$ by 8 people $(7.4 \%)$. Most of the respondents have their income per month above RM3000: 33 persons (30.6\%) and the rest have income per month between RM 1001-RM 2000 which is 23 persons (21.3\%), below RM500 which is 22 persons (20.4\%), RM 2001-RM 3000 which is 21 persons $(19.4 \%)$ and lastly RM 501-RM 1000 which is 9 persons $(8.3 \%)$ The mean score was recorded for income of the family (monthly income) is (RM1001RM 2000), while standard deviation is (< RM 500).

On the other hand, the employment status of respondent with the highest compositions is for Selfemployed ( 35 persons) which is $32.4 \%$, followed by private sector (33 persons) which is $30.5 \%$, unemployment (20 persons) which is $18.5 \%$ government sector (19 persons) which is $17.6 \%$ and retired ( 1 person) which is $9 \%$.

\section{Reliability Test Analysis}

Table 2 above shows the result of reliability test analysis for four items of variables regarding this case study. For the first variable which is attitude towards applications of online Halal label system in Malaysia. Given the value of Cronbach Alpha is 0.929 which conducting 15 items in questionnaire that is related to attitude. Next, value Cronbach Alpha at 0.914 each of 10 items for each variable for subjective norm, perceived behavior control and intention towards applications of online Halal Label in Halal label system in Malaysia. All the value of four variables is more than 0.6 , thus it shows that our study is consistency and relevant with the TPB [13]. So that, TPB is the suitable methods for our case study.

\section{Result of Pearson Correlation Analysis}

Testing relationship between intention and age of consumer using application of online halal label system in Malaysia

Table 3 shows the results of Pearson correlation analysis which is applied to measure the relationship for independent variable on the dependent variable. The correlation between intention and age of consumer that using application of online Halal label system in Malaysia is significant at level of 1.000 and has a positive correlation. Therefore, the result shows that the investigation of relationship between socio demographic and intention of consumer toward Halal label in Malaysia is reacted to each other. In other words, consumer with possible age appeared to have greater intention to use the application of online Halal label system.

Testing relationship between intention and monthly income of the family of consumer using application of online halal label system in Malaysia

Table 3 shows the results of Pearson correlation analysis which is applied to measure the relationship for independent variable on the dependent variable. The 
correlation between intention and monthly income of the family of consumer of consumer that using application of online Halal label system in Malaysia is significant at level of 0.539 and has a positive correlation. Therefore, the result shows that the investigation of relationship between sociodemographic and intention of consumer toward Halal label in Malaysia is reacted to each other. In other words, consumer with possible monthly income of the family appeared to have greater intention to use the application of online Halal label system.

Table 1: Socio-Demographic Profile of Respondent

\begin{tabular}{|c|c|c|c|c|}
\hline Variable & Frequency & Percentage (\%) & Mean & $\begin{array}{l}\text { Standard } \\
\text { Deviation }\end{array}$ \\
\hline $\begin{array}{l}\text { Gender } \\
\text { Male } \\
\text { Female }\end{array}$ & $\begin{array}{l}40 \\
68\end{array}$ & $\begin{array}{l}37.0 \\
63.0\end{array}$ & & \\
\hline $\begin{array}{l}\text { Race } \\
\text { Malay } \\
\text { Chinese } \\
\text { Indian } \\
\text { Other }\end{array}$ & $\begin{array}{c}96 \\
7 \\
2 \\
3\end{array}$ & $\begin{array}{c}88.9 \\
6.4 \\
1.9 \\
2.8\end{array}$ & & \\
\hline $\begin{array}{l}\text { Age (year) } \\
21-30 \\
31-40 \\
41-50 \\
51-60 \\
60 \text { and above }\end{array}$ & $\begin{array}{c}82 \\
17 \\
5 \\
3 \\
1\end{array}$ & $\begin{array}{c}75.9 \\
15.8 \\
4.6 \\
2.8 \\
0.9\end{array}$ & $21-30$ & $21-30$ \\
\hline $\begin{array}{l}\text { Education Level } \\
\text { No education } \\
\text { Primary school } \\
\text { Secondary school } \\
\text { Diploma /STPM } \\
\text { Degree } \\
\text { Postgraduate /PhD }\end{array}$ & $\begin{array}{c}0 \\
1 \\
15 \\
52 \\
32 \\
8\end{array}$ & $\begin{array}{c}0 \\
0.9 \\
13.9 \\
48.2 \\
29.6 \\
7.4\end{array}$ & & \\
\hline $\begin{array}{l}\text { Income of the family } \\
\text { < RM 500 } \\
\text { RM501-RM1000 } \\
\text { RM1001-RM } 2000 \\
\text { RM2001-RM } 3000 \\
>\text { RM 3000 }\end{array}$ & $\begin{array}{c}22 \\
9 \\
23 \\
21 \\
33\end{array}$ & $\begin{array}{c}20.4 \\
8.3 \\
21.3 \\
19.4 \\
30.6\end{array}$ & $\begin{array}{l}\text { RM1001- } \\
\text { RM } 2000\end{array}$ & $<$ RM 500 \\
\hline $\begin{array}{l}\text { Employment status } \\
\text { Self-employment } \\
\text { Government sector } \\
\text { Private sector } \\
\text { Retired } \\
\text { Unemployment }\end{array}$ & $\begin{array}{c}35 \\
19 \\
33 \\
1 \\
20\end{array}$ & $\begin{array}{c}32.4 \\
17.6 \\
30.6 \\
0.9 \\
18.5\end{array}$ & & \\
\hline
\end{tabular}

Table 2: Reliability Test Analysis

\begin{tabular}{|l|c|c|}
\hline Variables & Cronbach Alpha & Item N \\
\hline Attitude & 0.929 & 15 \\
\hline Subjective Norm & 0.914 & 10 \\
\hline Behaviour & 0.914 & 10 \\
\hline Intention & 0.914 & 10 \\
\hline
\end{tabular}


Application of Online Halal Label Among Consumer Intention Toward the Halal Label System in Malaysia

Table 3: Pearson Correlation Analysis

\begin{tabular}{|c|c|c|c|}
\hline Control variables & & Age & Monthly income of the family \\
\hline \multirow{3}{*}{ Intention } & Correlation & 1.000 & 0.349 \\
\cline { 2 - 4 } & Significant (2-tailed) & 0.000 & 0.000 \\
\cline { 2 - 4 } & N of valid class & 108 & 108 \\
\hline
\end{tabular}

\section{CONCLUSION}

In a conclusion, age and monthly income of the family in term of demographic is positively related to intention of consumer toward application of the online halal label in Malaysia. Significantly relationship was found between socio demographic and intention of consumer toward halal label in Malaysia. This research has shown that consumer has high intention to use online Halal label system in Malaysia because it can contribute more positive impact and beneficial such as consumer can excess to check either the product is halal and save to consume or not. This result had answered the objectives which is the relationship between sociodemographic and intention of consumer toward Halal label system in Malaysia.

\section{REFERENCES}

[1] Latif, I. A., Mohamed, Z., Sharifuddin, J., Abdullah, A. M., \& Ismail, M. M. (2014). A Comparative Analysis of Global Halal Certification Requirements. Journal of Food Products Marketing, 20(S1), $85-101$. https://doi.org/10.1080/10454446.2014.921869.

[2] Rezai G., Mohamed Z., Chiew F.C. and Shamsudin M.S., (2009) Concerns for halalness of halallabelled food products among Muslim consumers in Malaysia: Evaluation of selected demographic factors, Economic and Technology Management Review,4, 65-73.

[3] Rezai G. Mohamed Z. and Shamsudin M.S. (2015). Can Halal Be Sustainable? Study on Malaysian Consumers' Perspective, Journal of Food Products Marketing, 21, 654-666, https://doi.org/10.1080/10454446.2014.883583.

[4] Mohamed, Z., \& Ayob, M. A. (2015). Journal of Food Products Marketing Food Labels' Impact Assessment on Consumer Purchasing Behaviour in Malaysia, https://doi.org/10.1080/10454446.2013.856053.
[5] Aliff, M., Majid, A., Hafifi, I., \& Abidin, Z. (2015). Issues of Halal Food Implementation in Malaysia Issues of Halal Food Implementation in Malaysia, (August 2016).

[6] Ajzen, I., \& Fishbein, M. (1980). Theory of Reasoned Action. Social Psychology. https://doi.org/10.4135/9781483346427.n552.

[7] Yzer, M. (2013). Reasoned Action Theory. In The Sage Handbook of persuasion: Developments in theory and practice.

[8] LaMorte.W.W (2016). The Theory of Planned Behavior. From: http://sphweb.bumc.bu.edu/otlt/MPHModules/SB/ BehavioralChangeTheories/BehavioralChangeThe ories3.html.

[9] Melchers, R. E., \& Beck, A. T. (2018). Structural reliability analysis and prediction. John Wiley \&Sons.

[10] Trochim. M.K (2006) Descriptive Statistics. From: https://socialresearchmethods.net/kb/statdesc.php.

[11] Vicol.O \& Zait.A (2014) A country's image as tourist destination for external Intermediaries. Management \& Marketing Challenge for the Knowledge Society. 9(1), pp.47-74.

[12] Cohen, P., West, S. G., \& Aiken, L. S. (2014). Applied multiple regression/correlation analysis for the behavioural sciences. Psychology Press.

[13] Shah Alam, S. \& Mohamed Sayuti, N. (2011). Applying the Theory of Planned Behaviour (TPB) in halal food purchasing. International Journal of Commerce and Management, 21(1), 8-20. 